\title{
Development of a social impact assessment method and application to a case study of sugarcane, sugar, and ethanol in Thailand
}

\author{
Sawaengsak, Wanchat; Olsen, Stig Irving; Hauschild, Michael Zwicky; Gheewala, Shabbir H.
}

Published in:

International Journal of Life Cycle Assessment

Link to article, DOI:

$10.1007 / \mathrm{s} 11367-019-01624-8$

Publication date:

2019

Document Version

Peer reviewed version

Link back to DTU Orbit

Citation (APA):

Sawaengsak, W., Olsen, S. I., Hauschild, M. Z., \& Gheewala, S. H. (2019). Development of a social impact assessment method and application to a case study of sugarcane, sugar, and ethanol in Thailand. International Journal of Life Cycle Assessment, 24(11), 2054-2072. https://doi.org/10.1007/s11367-019-01624-8

\section{General rights}

Copyright and moral rights for the publications made accessible in the public portal are retained by the authors and/or other copyright owners and it is a condition of accessing publications that users recognise and abide by the legal requirements associated with these rights.

- Users may download and print one copy of any publication from the public portal for the purpose of private study or research.

- You may not further distribute the material or use it for any profit-making activity or commercial gain

- You may freely distribute the URL identifying the publication in the public portal 


\title{
The International Journal of Life Cycle Assessment https://doi.org/10.1007/s11367-019-01624-8
}

\section{Development of a social impact assessment method and application to a case study of sugarcane, sugar and ethanol in Thailand}

\author{
Wanchat Sawaengsak $^{1,2}$, Stig I. Olsen ${ }^{3}$, Michael Z. Hauschild ${ }^{3}$, Shabbir H. Gheewala ${ }^{1,2, *}$ \\ ${ }^{1}$ The Joint Graduate School of Energy and Environment (JGSEE), King Mongkut's University of Technology \\ Thonburi, 126 Prachauthit Road, Bangkok 10140, Thailand
}

${ }^{2}$ Centre of Excellence on Energy Technology and Environment, PERDO, Bangkok, Thailand

${ }^{3}$ Department of Management Engineering, Section for Quantitative Sustainability Assessment, Technical University of Denmark (DTU), Produktionstorvet Bygning 426, 2800 Lyngby, Denmark

*Corresponding author, E-mail address: shabbir_g@jgsee.kmutt.ac.th,

Tel: (66)(2)470 8309/10 ext. 4139, Fax: (66)(2)872 9805

\begin{abstract}
Purpose The implementation of midpoint, endpoint and single score assessments to support decision-making remains a major challenge for developing a coherent social impact assessment methodology. The simple weighted sum approach and normalization technique for single score assessments have been problematic and the final results do not realistically represent stakeholder perspectives due to mis/over-interpretations. The focus of this study is to develop a weighting scheme for social impact assessment. The developed scheme is then evaluated using a case study on social impact assessment of the sugarcane sector in Thailand.

Methods A weighted aggregation method has been developed for assessing different categories and sub-categories of social dimensions. The performance indicators for each sub-category determine the accuracy of the impact results by establishing the rating weight of the importance of social aspects and satisfaction. The developed method is then applied to a case study on sugarcane-based ethanol production in Thailand. The stakeholders involved in the sugarcane sector comprising sugarcane, sugar and ethanol production include cane growers, cane workers, sugar factory and ethanol factory workers. The social issues related to stakeholders in sugarcane, sugar and ethanol production must fit the cause-effect chain, which can help not only defining the specific social aspects to meet the appropriate subcategories and performance indicators but also facilitating the data collection.
\end{abstract}


Results and discussion The characterized/inventory result can be improved by using the weighting factor of importance of social aspects and satisfaction. The results of the social impact performance score reveal that including the weighting of the importance of social aspects and satisfaction affect the result of the impact sub-categories and social categories. The case study revealed that the relevant impact categories of cane growers are 1) land tenure, 2) access to knowledge, facility and natural resources, 3) employment, wages and labor conditions 4) equity and 5) human health and safety. On the other hand, the impact categories of cane workers, sugar factory workers and ethanol factory workers are 1) decent livelihood, 2) labor rights, 3) equity, and 4) human health and safety.

Conclusions The social impact assessment method with developed weighting scheme can help the government and private sectors prioritize their efforts in minimizing negative social impacts throughout the life cycle of biofuel systems. However, the data on the importance of social aspects and satisfaction is subjective; uncertainty analysis or sensitivity analysis must therefore be applied to further observe the variation of different options to facilitate decision making.

Keywords: social life cycle assessment, social impact assessment, methodology development, sustainability, sugarcane, sugar, ethanol production, biofuel, Thailand

\section{Introduction}

Social life cycle assessment (S-LCA) is increasingly being used for assessing both positive and negative social impacts throughout the life cycle of products (UNEP 2009). A recent review has shown that $35 \%$ of the studies addressing sustainability issues use life cycle economic/environmental indicators. However, only $17 \%$ of the studies include the social dimension probably due to the lack of a widely accepted methodology for social life cycle assessment (S-LCA) (Martín-Gamboa et al. 2017).

Various S-LCA methods have been developed in the recent years, the distinction being based on the types of data. The choice of the S-LCA method can affect the result depending on the different evaluation systems (Wang et al. 2009; Ibáñez-Forés et al. 2014). S-LCA data may be of three types: quantitative, semi-quantitative (yes/no or rating scale responses) and qualitative (descriptive text) (UNEP 2009). There are broadly two classes of S-LCA methods; Type I uses a qualitative/semi-quantitative, scale-based approach (scoring system) through the performance reference points (PRPs) to assess the social performance which can be positive or negative (Ciroth and Franze 2011; Quantis et al. 2012; Fontes 2014). Here, the weighting approach uses the personal or collective judgements by interviewing a 
panel of experts and decision makers in their related field or by applying the Delphi method, pair-wise comparison and Analytic Hierarchy Process (AHP) (Manik et al. 2013; Yu et al. 2012; Giner-Santonja et al. 2012). On the other hand, Type II uses impact pathways through characterization models which are typically quantitative as mid-point and endpoint indicators (UNEP 2009; Parent et al. 2010; Weidema 2006). In this case, rational approaches are applied by using a statistical model or quantitative criteria (Yang et al. 2009).

Comprehensive and analytical reviews of S-LCA approaches have recently been conducted to examine the multiplicity of approaches developed for Type I S-LCA from 2006 - 2015 (Russo Garrido et al. 2018). The use of weighted characterization results can often be aggregated into impact categories on the basis of equal weighting or the relative importance of social aspects. Furthermore, Type I assessment methods mostly use the PRP scale system (Chhipi-Shrestha et al. 2015; Parent et al. 2010). This is usually performed by five (or seven) point scales or binary (yes/no questions) which are used to reflect the level of compliance with international or national laws, sectoral norms and best practice (Ciroth and Franze 2011; Fontes 2014; Blok et al. 2013; Sanchez Ramirez et al. 2014; Aparcana and Salhofer 2013a). However, the rating scales which are determined to some extent through expert judgment can mask the decision dependency of weighting scheme. This may cause a high uncertainty associated with quantification of weights (Carmo et al. 2017a).

An example of Type I S-LCA is a study by Spillemaeckers et al. (2004). It presents a rating on occupational health and safety using statistical data of several indicators related to health and safety and translated into numbers using a scoring system. However, the problem of rating score through the number of working accidents as an indicator, for example, is that the low number of indicator may reflect either strongly efficient management practice or poor database management system (Jørgensen et al. 2008; Preyer 2006). Manik et al. (2013) applied a scoring system for weighting the social expectations and perceptions of social issues from impact categories. The weighting process was performed using a questionnaire involving a panel of experts and decision-makers in the palm oil industry to reflect the importance level of sub-categories. Another study by Hosseinijou et al. (2014) undertook a material flow analysis (MFA) to weight the importance of life cycle steps and then performed an expert judgment to aspects identify the most important of socio-economic issues. However, the method for weighting the importance of social aspects according to stakeholders or expert opinion may introduce a biased judgment.

Another issue is that although there are several social criteria/indicators from different stakeholders, it needs to be considered whether the impact of social criteria to stakeholders is positive or negative (UNEP 2009; Feschet et al. 
2012; Dreyer et al. 2010). If there are some ambiguous outcomes, how can the social criteria/indicators be simplified in terms of scoring system or in quantitative terms? For example, long working hours may be bad for workers in term of health conditions but good for the growers/farm owners from another point of view. This sort of dilemma is a challenge for social life cycle assessment. Measurement of social indicators based on preference values of stakeholders (rating score) is likely to be subjective and is often associated with high uncertainty (Carmo et al. 2017a). In terms of the environmental and economic aspects, the uses of monetary terms like willingness to pay (WTP) are capable of sorting the importance of social aspects from stakeholder preferences by considering how much a stakeholder is willing to pay. But for the social aspects, it is somehow difficult to find a practical way due to subjective evaluation of stakeholder perspective. The cause-effect chain in environmental life cycle impact assessment (LCIA) can provide a useful structure for the development of a broader sustainability assessment methodology and helps to pursue ultimate scores, assessing trade-offs between different phases in the life cycle and different impacts in an overarching and comprehensive way (Blok et al. 2013).

Moreover, the essential components for accuracy of the weighting score include the data type, stakeholder perception and methodology, all of which play a role in determining the quality of the data and thus, accuracy and reliability of outcomes. The data quality is also considered as a score along with the impact results of sub-categories and social categories depending on whether the data are primary, secondary or estimated. Although the score rating of data quality is excluded from calculating the impact of sub-categories (FAO 2014), it is important to address the data quality in the report as it represents the reliability and validity of the results (UNEP 2009).

Stakeholder perception has generally been used for assessing satisfaction in the field of social science (Kroeger and Weber 2014). A satisfaction survey is designed to monitor stakeholder perception of the degree to which their needs are fulfilled regarding the social aspects.

Based on the above literature review, there are a variety of developed approaches within Type I S-LCA but with gaps that need further consideration, viz., 1) the issues of the scoring system, 2) the issues of the use of a weighting scheme, and 3) a lack of systematic identification of relevant stakeholders and social issues. In order to address these issues, a systematically comprehensive and reliable framework and method for S-LCA needs to be developed.

Therefore, the objective of the study is to develop a general social impact assessment framework and method to illustrate its application via a case study evaluating the social impact of biofuel systems comprising sugarcane, sugar and ethanol production. 


\section{Methods}

In the connection with the objective of the study, it was hypothesized that the reliability of impact assessment results could be improved by proposing additions to the existing S-LCA framework as well as to the impact assessment methodology. To do so, the existing studies were therefore reviewed to identify issues which could potentially limit the use of social life cycle impact assessment (SLCIA) to applications (Section 2.1). The limitations identified in the studies are considered for alleviating the problems in the framework and method for the assessment of social impacts associated with the life cycle of product systems leading to a pathway for improving the existing S-LCA framework and method (Section 2.2). A case study is then identified for assessing the social impact of sugarcane-based ethanol production using the S-LCA method to be developed (Section 2.3).

\subsection{Literature review of methods for developing a framework and SLCIA method}

Literature based on the recent works of the review articles on S-LCA methods (Russo Garrido et al. 2018; Chhipi-Shrestha et al. 2015; Wu et al. 2014) was searched through web-based research studies. These articles conducted a comprehensive review of current developed frameworks, methods, and characterization models for social impact assessment. Nevertheless, these reviewed articles have identified the issues for future development and research needs. In order to develop an improved framework and SLCIA method, the relevant articles were reviewed with a focus on selecting of indicators, scaling of inventory data, characterization, and weighting methods.

\subsubsection{Selecting of indicators}

Indicators are used to link the data with subcategories and impact categories guiding the data collection process. Direct indicators are typically developed; however, some studies used indirect indicators because the direct indicators cannot explain the complexities associated with social issues (Dreyer et al. 2010; Aparcana and Salhofer 2013a; Foolmaun and Ramjeeawon (2013). The Type I characterization model does not incorporate causal relationships and the indicators are aggregated with a scoring system.

\subsubsection{Scaling of inventory data}

There is a variety of scoring systems applied to SLCIA methods as depicted below.

Dreyer et al. (2010) developed a framework and characterization model using multi-criteria indicators taking the issue of labor rights as an example. This model was based on a scorecard applied to assess the effort or ability of a company to manage a given social issue as the indirect indicator. However, the study is based on traditional industries 
and considered only the workers. Similarly, Traverso et al. (2012) considered social impacts of photovoltaic (PV) modules only on the workers at the manufacturing stage. On the other hand, Sanchez Ramirez et al. (2014) proposed the subcategory assessment method (SAM), which used a different approach accounting the corporate performance related to the management practices both as indirect as well as direct indicators.

Ciroth and Franze (2011) considered several stakeholder groups and developed a scoring system using six performance levels: very good, good, satisfactory, inadequate, poor and very poor performance levels, and six impact levels: positive, lightly positive, indifferent, lightly negative, negative and very negative effect. Although this method gave an equal weighting to subcategories, all subcategories and stakeholders may not be equal in relevance.

Manik et al. (2013) assessed the social implications of palm oil biodiesel by combining the stakeholders' survey and expert evaluation. A seven-point Likert scale was used to gauge both social expectation and perception by considering four stakeholder categories: value chain actors, workers, local community and society. Also, the weighting of the importance of social aspects was identified by the experts at the data collection stage. However, this method for weighting the importance of social aspects according to stakeholders or expert may introduce a biased judgment.

Aparcana and Salhofer (2013a) proposed a binary (yes/no type of response) by scoring 1 for fulfillment and 0 for non-fulfillment of each of the 26 social criteria assigned by stakeholder interviews. Nevertheless, the study allowed the stakeholders to rate the satisfaction level on a scale of 1 (very bad), 2 (bad), 3 (medium), 4 (good) and 5 (very good). However, the use of scaling of inventory data on the functional unit is not associated with the social impact results which may cause a problem on data validation when applying to other systems.

\subsubsection{Characterization}

The characterization model is typically used to provide the inventory indicators to sub-categories or impact categories through causal relationships. The use of PRPs in Type I assessment methods for different studies has been on different scales (Ciroth and Franze 2011; Quantis et al. 2012; Fontes 2014). This may lead to difficulty in comparison of the results in the same social aspects across different studies. So, a proper characterization for impact categories and subcategories is needed.

\subsubsection{Weighting methods}

The weighting according to stakeholders/experts judgment can usually be based on the relative importance attributed to different sub-categories of the stakeholder group. The different values of the issues which were determined through expert judgment were likely to affect the impact categories. Manik et al. (2013) selected third- 
168

169

170

171

172

173

174

175

176

177

178

179

180

181

182

183

184

185

186

187

188

189

190

191

192

193

194

195

party stakeholders including academia, an activist organization, NGOs, and government agencies. Hosseinijou et al. (2014) focused on 20 experts in the fields of business. The results of the social assessment may thus depend on the set of stakeholders selected.

Based on the literature review above, the needs for improvement or addition to the general impact assessment methodology of the S-LCA are as follows;

- Incorporating the causal relationships and aggregating the indicators with a scoring system (Section 2.1.1)

- Covering all dimensions of social aspects collected from different experts and stakeholders (Section 2.1.4)

- Enhancing the linkage between functional unit and inventory data to social impacts (Section 2.1.2)

- Providing the basis for the use of PRPs in Type I assessment methods and a consistent characterization for impact categories and subcategories (Section 2.1.3)

- Developing an appropriate weighting scheme considering the relative importance of social aspects, and aggregating the characterization result into impact categories, stakeholder categories, or even in a single score (Section 2.1.2)

2.2 Procedure details for developing a framework and SLCIA method

The general framework for SLCIA used in this study was the one proposed by the UNEP-SETAC Life Cycle Initiative. The SLCIA phase consists of three mandatory steps following ISO 14044 (2006) for LCIA, which include; Selection of impact categories and characterization methods and models; Linkage of inventory data to particular SLCIA subcategories and impact categories (classification); Determination and/or Calculation of subcategory indicator results (characterization) (UNEP 2009). The framework is an open space for future development.

The procedural details for developing a framework and SLCIA method follow the general framework steps which include; Step 1 Providing the social categories, sub-categories, and indicators; Step 2 Measuring the inventory/characterization results of indicators; Step 3 Determining the weighting factor at the sub-categories level; Step 4 Aggregation of results of performance score at sub-category and social category level.

Step 1 Providing the indicators, sub-categories, and social categories

The global default indicators, sub-categories and social categories on social and socio-economic aspects are normally used for systematic evaluation of performance outcomes. However, there are variations in the social and 
socio-economic context which differ in temporal scope and timing of the data collection. Some default indicators may not be relevant in some types or contexts of performance measurement. Using existing data allows the S-LCA practitioners to save time and money in completing the SLCIA but may create variances and subjectivity of impact results. Directly collecting the data needed has the advantage of being specifically fit to the SLCIA method and indicators. In some cases, the social issues are specified through expert knowledge and stakeholder experience by applying the cause-effect chain analysis. The analysis generates the relationship between the possible cause and effect of social aspects within a process by asking the experts and stakeholder to list the problems. This step follows a causeeffect analysis which is anticipated to facilitate the choice of indicators, sub-categories and social categories.

\section{Step 2 Measuring the inventory/characterization results of indicators}

The purpose of this step is to measure and aggregate the inventory/characterization results of indicators to subcategories or impact categories through causal relationships. This involves the calculation of indicator results and conversion of inventory results to a common metric. However, some social and socio-economic impacts might be best captured through qualitative, semi-quantitative, or quantitative indicators depending on the context of the issue at site. These types of indicators are not always formalized in terms of quantitative assessment. For example, semiquantitative indicators cannot directly be expressed per unit output. But these can be categorized as qualitative indicators and measured into a "yes" or "no" form or a scale (scoring system). Therefore, the scoring system is crucial to this end. In this step, the characterization is conducted upon data collection, when the stakeholders are asked whether compliance or non-compliance with norms or best practice is performed. The frequency of the stakeholder response is then converted to a percentage score and translated to a rating score.

\section{Step 3 Determining the weighting factor at the sub-categories level}

Sometimes the inventory/characterization results cannot reflect the reality of social issues in a specific context. For example, the social issue of freedom of association and rights to collective bargaining is probably not a problem for the workers because they may not recognize that the rights will be essential for them. A number of studies have used weighting the importance of social aspects according to expert judgment and stakeholder perception (Manik et al. 2013; Hosseinijou et al. 2014). However, the framework is developed to combine weighting according to expert judgment and stakeholder satisfaction by allowing the stakeholders to rate the satisfaction levels of social performance. Step 4 Aggregation of results of performance scores at sub-category and social category level 
To obtain a performance score at the social category level, several sub-category scores have to be aggregated into a single score. This is obtained by calculating an arithmetic mean of the sub-category scores. However, the aggregated results have lost some information and risk relevant information being masked. To address this limitation, all sub-categories will include data quality scores which are useful for making a decision and identifying areas of improvement.

2.3 Case study for application of developed S-LCA method

To illustrate the developed S-LCA framework and impact method developed, a case study was conducted on SLCA of sugarcane, sugar and ethanol production. The inventory data of the social indicators were collected from an earlier study by Sawaengsak and Gheewala (2017). Based on the study, the system boundaries proposed include: sugarcane production stage (land preparation, planting, maintenance, and harvesting), transportation stage, sugar production stage (production process and management), and ethanol production stage (conversion process and management).

The expert judgment and stakeholder satisfaction were collected from primary sources through face-to-face interviews via questionnaires. The study area was Nakhon Ratchasima province, the largest sugarcane cultivation and sugar/ethanol production area in Thailand. The study sites (farms) were randomly selected for three different sugar factories located in Nakhon Ratchasima province.

The selected experts were the representatives of each stakeholder group and thus trusted by stakeholders. The experts, who were the representatives of the private sector (three groups: village heads, cane grower heads and heads of agricultural promotion from sugar factories) and government sector (two groups: directors of provincial agricultural office and heads of local agricultural promotion office) with relevance to sugarcane-based ethanol business, were asked questions to identify and verify the importance of social aspects involving the stakeholders. Each group of experts was represented by five participants.

Moreover, stakeholder groups were selected on the basis of the social issues identified by the experts in the interviews. The stakeholders considered in the study included cane growers and cane workers for sugarcane production, sugar factory workers for sugar production and ethanol factory workers for ethanol production. For each type of stakeholders, at least 30 participants were sampled as a conservative minimum sample size.

\section{Results and discussion}

3.1 The result of developed framework for SLCIA 
To address the reliability of impact assessment results, the procedure for improvement or addition to the existing

252
S-LCA framework (Section 2.2) underlying the social impact assessment of production systems is described below.

The procedure for the measurement of impact performance of social categories related to stakeholders is shown in Fig. 1. The cause-effect relationship is established in the very beginning so as to identify and select the relevant social impact indicators, sub-categories and social categories (indicated in Fig. 1 as "Identification of the impact category" box).

After that, the characterization is applied to calculate the selected impact indicators related to stakeholders (indicated in Fig. 1 as "Characterization" box). The rating scores of inventory results/characterized results of indicators $(\mathrm{CR})$ are assigned to facilitate aggregation of score-based actual results $\left(\mathrm{ACT}_{\mathrm{CR}}\right)$ and the actual performance results $\left(\mathrm{PR}_{\mathrm{act}}\right)$.

Simultaneously, the weighting of the importance of social aspects (I) and satisfaction (S) are calculated based on scoring of the expert judgment and stakeholder satisfaction (shown in "Weighting factor" box). The weighted results of the importance of social aspects and satisfaction $\left(\mathrm{W}_{\mathrm{i.s}}\right)$ are calculated to obtain the adjustment factor of I and $\mathrm{S}$ $\left(\mathrm{AF}_{\mathrm{i} . \mathrm{s}}\right)$.

The results from the characterization and weighting process are combined to obtain the adjusted performance result $\left(\mathrm{PR}_{\mathrm{adj}}\right)$. The adjusted performance result $\left(\mathrm{PR}_{\mathrm{adj}}\right)$ can be assigned a rating score to present the adjusted performance score $\left(\mathrm{PS}_{\text {adj }}\right)$ for measuring the impact performance at sub-category level and integrating into the impact performance score (IPS) at social category level (shown in "Results of impact performance" box). 
Identification of the impact category

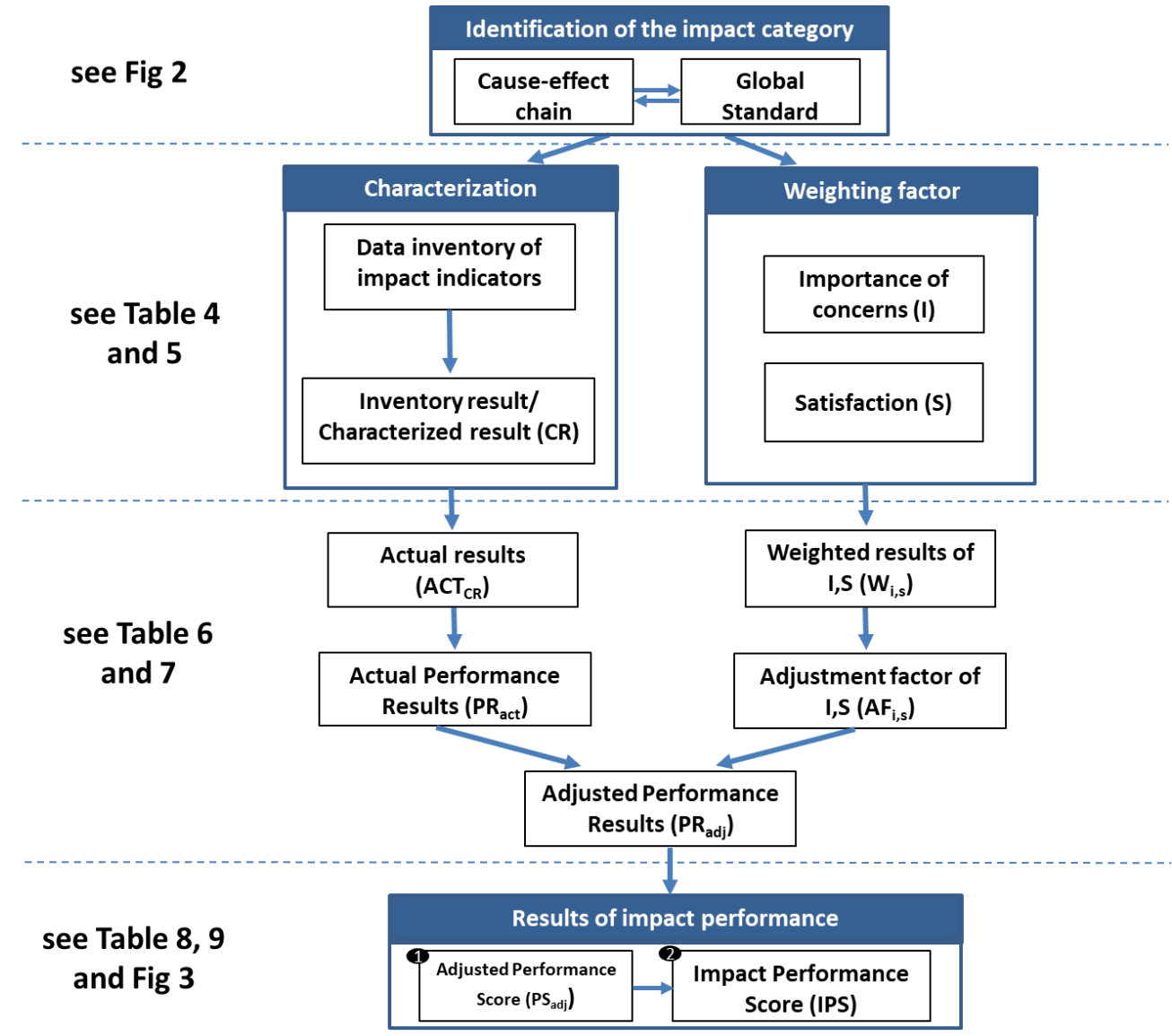

Fig. 1 Framework of the developed social impact assessment

3.2 The result of developed method for SLCIA

The procedure outlined in the framework developed above is applied to a case study of sugarcane-based ethanol

274 production system. This section gives the details of all steps in the SLCIA methodological development and how to calculate the impact results.

The developed method consists of four main steps of developing social impact assessment including; Step 1:

277 Providing the social categories, sub-categories, and indicators; Step 2: Measuring the inventory/characterization 278 results of indicators; Step 3: Determining the weighting factor at the sub-categories level; and Step 4: Aggregation of results of performance score at sub-category and social category level. The steps are described the details in the following:

Step 1: Providing the indicators, sub-categories, and social categories

To find all possible causes of social issues associated with the stakeholders, the cause-effect chain was determined 
284 (three groups: village heads, cane grower heads and heads of agricultural promotion from sugar and ethanol factories) and government sector (two groups: directors of provincial agricultural office and heads of local agricultural promotion office) with relevance to sugarcane-based ethanol business. Each group of experts was represented by five participants. The stakeholders include cane growers (41 participants), cane workers (44 participants), sugar factory workers (30 participants) and ethanol factory workers (42 participants). The study focuses on male/female workers, status (single or married), aged 18-65 and education level (primary school - university). The growers are contracted with the sugar factory for a small-scale plantation (with areas of less than $10 \mathrm{ha}$ ). The workers are classified by employment type (part-time/full-time work) and worker type (local/non-local workers).

The specific social issues derived from the cause-effect analysis should be relevant to the social category, subcategories and performance indicators. The relevant social category, sub-categories and performance indicators should cover human rights and social well-being in the products related to bioenergy and agricultural system. The assessment based on standards, norms and best practices related to the social indicators is from the international standards for social sustainability including Bonsucro (Bonsucro 2014), Global Bioenergy Partnership (GBEP) (FAO 2011) and the Sustainability Assessment of Food and Agricultural Systems (SAFA) (FAO 2014). The assessment is made at three levels:

1. Specific social issues: social issues related to stakeholder groups that found at site are measured, such as

- Cane growers: land rights, labor shortage and high cost/low income of production

- Cane workers/sugar and ethanol factory workers: labor rights, quality of life, and health and safety

2. Impact sub-categories: social sub-categories for each of the specific social issues, for example,

- Cane growers: land rights; employment; training for health and safety; labor condition; access to knowledge, facility and natural resource; and fair wage/income

- Cane workers/sugar and ethanol factory workers: non-discrimination; forced labor; child labor; gender equality; quality of life; capacity development; fair access to means of production; and workplace safety and health provisions

3. Impact categories: social categories for each of the social sub-categories, for example,

- Cane growers: land tenure; employment, wage and labor conditions; access to knowledge, facility and natural resource; health and safety 
- Cane workers/sugar and ethanol factory workers: equity; labor rights; decent livelihood; human health and safety

The interrelationship between a cause-effect chain related to stakeholder groups and the global standard for social sustainability is illustrated more fully in Figures $2 a$ and $2 b$. The questionnaire and selected indicators used in the characterization model are provided in the Electronic Supplementary Material (ESM).

\section{Step 2: Measuring the inventory/characterization results of indicators}

The questions related to the social indicators are from the global standard for sustainability including Bonsucro,

GBEP and SAFA. However, some of the questions need to be adjusted to be relevant to the specific location and type of data. The characterization method which is used in this study is applied through compliance with norms or best practice performed with a binary scale (yes/no). The indicators and their norms used in characterization model are provided in the Electronic Supplementary Material (ESM). The percentage of indicators is calculated from the number of growers/workers answering yes/no questions and a total number of growers/workers, presented by Equation 1 . The resulting indicator score is expressed as an actual score $\left(\mathrm{ACT}_{\mathrm{CR}}\right)$ of indicators through a scoring system (Table 1). The outcomes of this characterization process are the actual performance results $\left(\mathrm{PR}_{\mathrm{act}}\right)$ which are obtained by comparing an actual score $\left(\mathrm{ACT}_{\mathrm{CR}}\right)$ with ideal performance $\left(\mathrm{ACT}_{\max }\right)$, as Equation 2 and expressed as a value between 0 and 1.

- The inventory/characterization results (CR) of indicators are calculated as follows:

$$
C R=\frac{\text { Number of growers } / \text { workers answering yes } / \text { no to indicator question }}{\text { Total number of growers } / \text { workers }} \times 100
$$

Table 1 Classification of inventory/characterization results for rating score

\begin{tabular}{cc}
\hline Characterized result $(\mathbf{C R})$ & Score of $\mathbf{A C T}_{\mathbf{C R}}$ \\
\hline $80 \%<\mathrm{CR} \leq 100 \%$ & 5 \\
$60 \%<\mathrm{CR} \leq 80 \%$ & 4 \\
$40 \%<\mathrm{CR} \leq 60 \%$ & 3 \\
$20 \%<\mathrm{CR} \leq 40 \%$ & 2 \\
$0 \% \leq \mathrm{CR} \leq 20 \%$ & 1 \\
\hline
\end{tabular}

$$
P R_{a c t}=\frac{\sum A C T_{C R}}{\sum A C T_{\max }}
$$


$\sum A C T_{C R}$ is a sum of all actual scores of the indicator in a sub-category. $\sum A C T_{\max }$ is a sum of actual scores of

the indicator under ideal performance in a sub-category. $A C T_{\max }$ assumes that the actual score is being rated under ideal performance at the best level which will have a score of 5 .

\section{Step 3: Determining the weighting factor at the sub-categories level}

A three-point scale has been used on the importance of social aspects, data quality and satisfaction which are characterized as "high", "moderate" or "low" importance, quality and satisfaction respectively. The principles and procedures of rating score of Importance of social aspects (I), Data quality (D) and Satisfaction (S) are illustrated in Table 2. After all the rating scores of I, D and $\mathrm{S}$ are obtained, the weighted score $\left(W_{i . s}\right)$ can be calculated by multiplying $I$ and $S$, as Equation 3. The adjustment factor of $\mathrm{I}$ and $\mathrm{S}\left(A F_{i . s}\right)$ is then obtained by dividing $\mathrm{W}_{\mathrm{i} . \mathrm{s}}$ by $\mathrm{W}_{(\mathrm{i} . \mathrm{s}) \text { max }}$, as Equation 4

Table 2 Principles of rating score of the importance of social aspects, data quality and satisfaction of sub-categories

\begin{tabular}{|c|c|c|c|}
\hline \multirow{2}{*}{ Score level } & \multicolumn{3}{|c|}{ Principle of rating score } \\
\hline & $\begin{array}{l}\text { Importance of social aspects } \\
(\mathbf{I})^{1}\end{array}$ & Data quality $(D)^{2}$ & Satisfaction (S) \\
\hline $\begin{array}{l}\text { High } \\
(3)\end{array}$ & $\begin{array}{l}\text { Less important of specific } \\
\text { social aspects }\end{array}$ & $\begin{array}{l}\text { Interviews with stakeholders and experts by } \\
\text { performing a triangulation technique or } \\
\text { using multi-question to verify the collected } \\
\text { data }\end{array}$ & Satisfied \\
\hline $\begin{array}{l}\text { Moderate } \\
\text { (2) }\end{array}$ & $\begin{array}{l}\text { Moderate important of specific } \\
\text { social aspects }\end{array}$ & $\begin{array}{l}\text { Documents (existing studies or relevant } \\
\text { studies) with a peer-reviewed source }\end{array}$ & Neutral \\
\hline $\begin{array}{l}\text { Low } \\
(1)\end{array}$ & $\begin{array}{l}\text { Most important of specific } \\
\text { social aspects }\end{array}$ & Relevant data which is older than 5 years & Unsatisfied \\
\hline
\end{tabular}
(I) and satisfaction (S) as follows:

$$
W_{i-s}=I \times S
$$

$$
A F_{i . s}=\frac{W_{i . s}}{W_{(i . s) \cdot \max }}
$$


$W_{i . s}$ is a weighting score per sub-category. $W_{(i . s) \text {.max }}$ is a weighting score under ideal performance per sub-category.

$W_{(i . s) \cdot \max }$ assumes that the importance of social aspects and satisfaction is being rated under ideal performance at the best level which will have a score $9(3 \times 3)$.

Step 4: Aggregation of results of performance score at sub-category and social category level.

The adjusted performance result $\left(P R_{a d j}\right)$ is calculated by multiplying $P R_{a c t}$ and $A F_{i . s}$, as Equation 5;

- $\quad$ The adjusted performance results $\left(P R_{\text {adj }}\right)$ are calculated as follows:

$$
P R_{a d j}=P R_{a c t} \times A F_{i . s}
$$

- Scoring $P R_{\text {adj }}$ to the performance score $\left(P S_{a d j}\right)$ by using a rating system (Table 3)

Table 3 Classification of rating system for the adjusted performance score $\left(P S_{a d j}\right)$

\begin{tabular}{c|ll}
\hline Adjusted performance result $\left(\mathbf{P R}_{\mathbf{a d j}}\right)$ & Adjusted performance score $\left(\mathbf{P S}_{\mathbf{a d j}}\right)$ & Rating definition \\
\hline $0.80<\mathrm{PR}_{\mathrm{adj}} \leq 1.0$ & 5 & Best \\
$0.60<\mathrm{PR}_{\mathrm{adj}} \leq 0.80$ & 4 & Good \\
$0.40<\mathrm{PR}_{\mathrm{adj}} \leq 0.60$ & 3 & Moderate \\
$0.20<\mathrm{PR}_{\mathrm{adj}} \leq 0.40$ & 2 & Limited \\
$0.0 \leq \mathrm{PR}_{\mathrm{adj}} \leq 0.20$ & 1 & Unacceptable \\
\hline
\end{tabular}

- Aggregating PS $S_{\text {adj }}$ to the impact performance score (IPS) at social category level

After getting $P S_{a d j}$, IPS is then obtained by calculating an arithmetic mean of all $P S_{a d j}$ at sub-category level. If the calculated value happens to be 0.5 , this would be rounded downward to the lower score.

3.3 The results of application to the case study

3.3.1 Cause-effect relationship towards the social issues and social indicators

The cause-effect chains were achieved through interviews yielding expert opinions and stakeholder perspectives on the problems specific to their role. By considering all possible causes of social issues related to stakeholders, the set of social performance indicators, sub-categories and social categories were selected by including the issues of relevance and data availability. According to the Sustainability Assessment of Food and Agricultural systems (SAFA) guidelines developed by Food and Agriculture Organization of the United Nations (FAO), the indicators, sub-categories and social categories of selected stakeholders are chosen by linking the inventory data through the cause-effect chain as illustrated in Fig. 2(a) and (b). The five relevant impact categories of cane growers are chosen including; 1) land tenure; 2) employment, wages, and labor conditions; 3) access to knowledge and facilities; 4) equity; and 5) health and safety. On the other hand, the four relevant impact categories of cane workers, 

health and safety.

(a) Cane growers

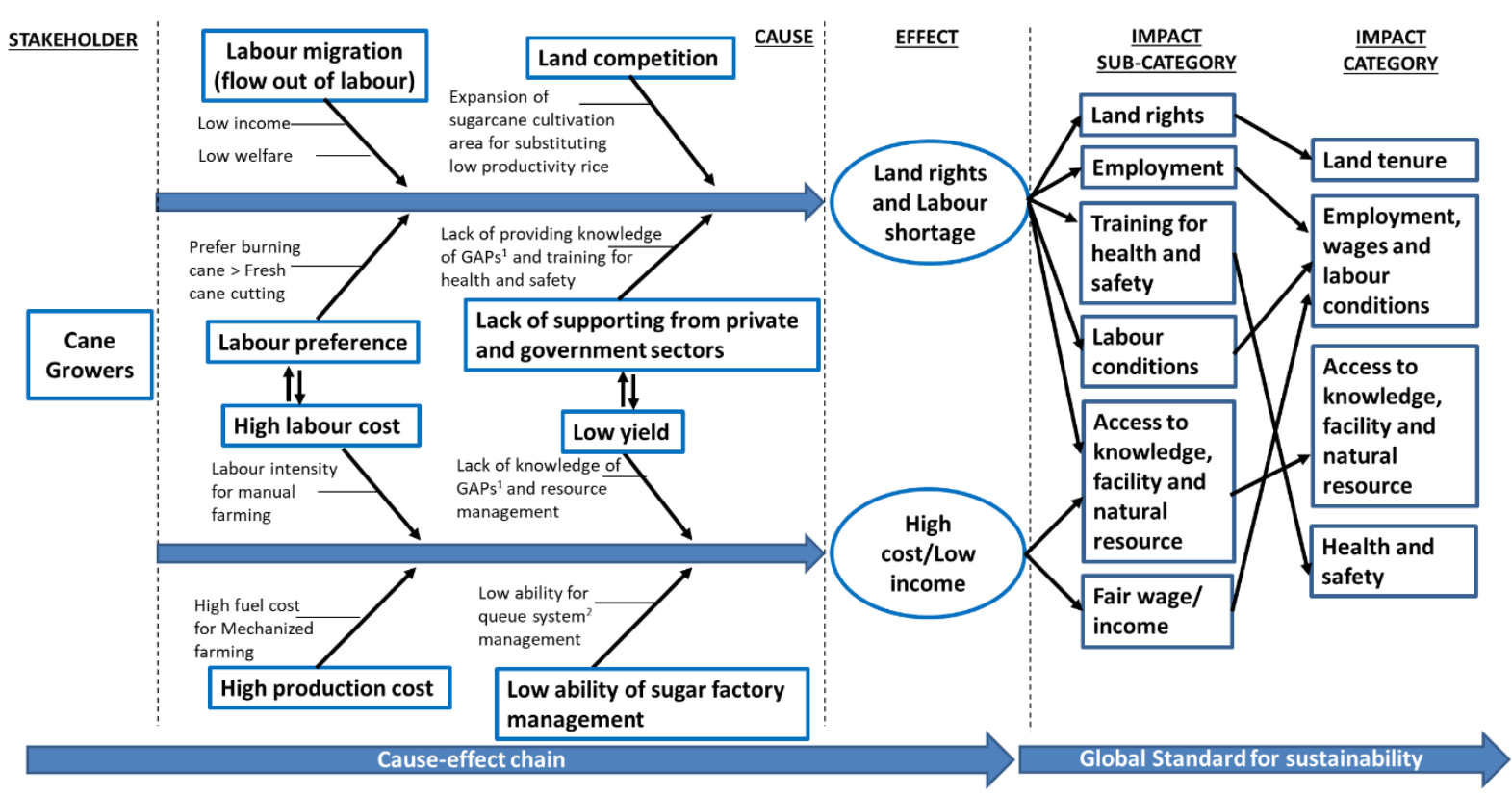

(b) Cane workers, Sugar factory workers and Ethanol factory workers

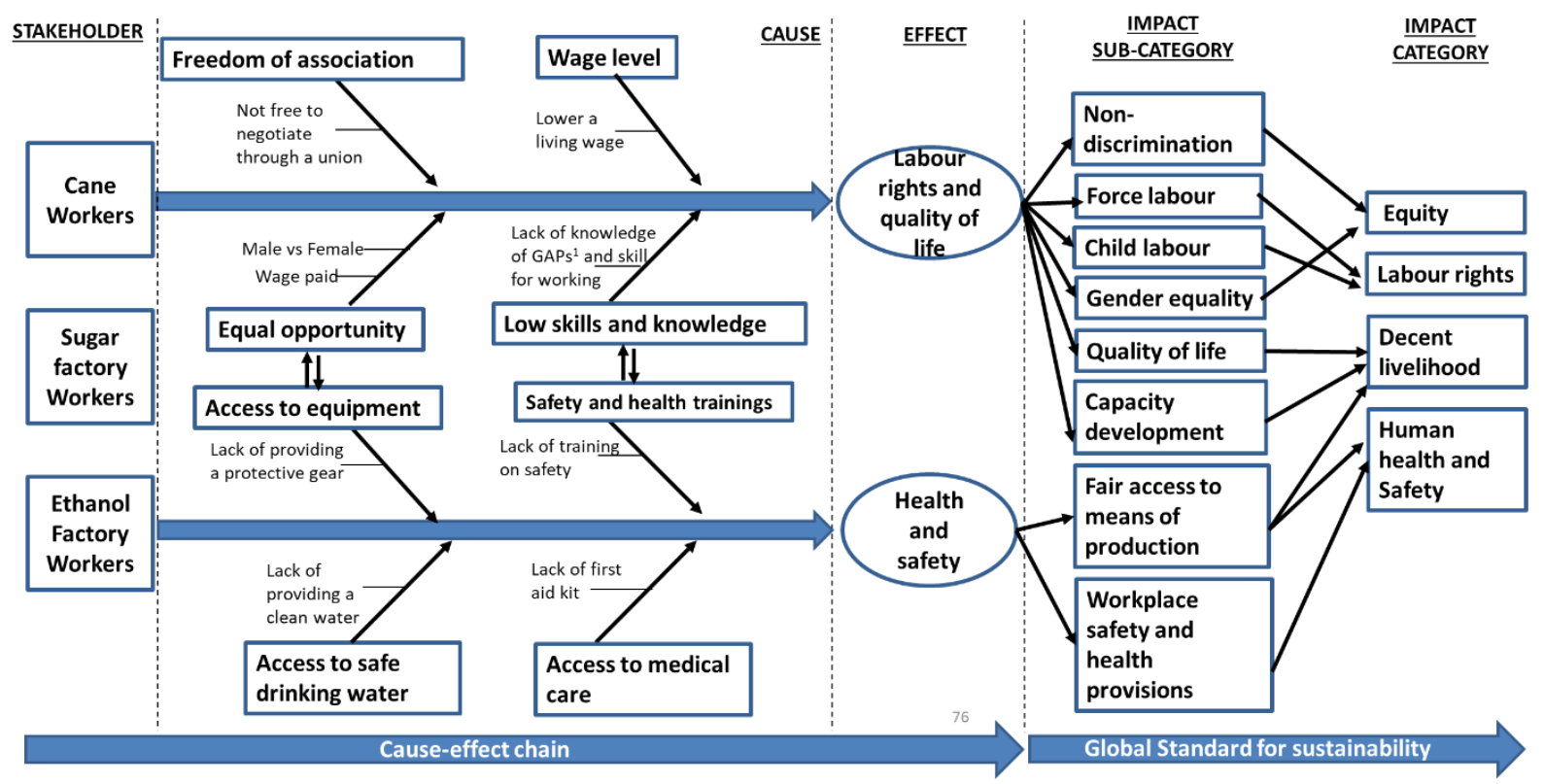

Fig. 2 The cause-effect relationship towards the social issues associated with stakeholders; (a) Cane growers and (b) 
Violations of land rights and labor shortage (Fig. 2(a))

The effect of land rights and labor shortage related to cane growers mainly derives from labor preference of agricultural practices, labor movement, land competition and lack of support from the sugar factory and agricultural extension. The expansion of sugarcane cultivation area which replaces rice cultivation can contribute to both land rights and labor shortage issues. Promotion of the policy by the Thai government on land conversion from low productivity rice field to sugarcane has resulted in land competition. This is because the cane growers acquire the land and natural resources from other growers for expanding their plantation area. The labor migration considering interregional labor mobility is relevant in affecting labor shortage during the harvesting season. The low wage/income rate and welfare is the crucial variable when making a migratory decision. The lack of providing knowledge of the good agricultural practices (GAPs) and health and safety training program from the private and government sector can also make the cane workers unaware of the effect of burning cane practice on the local community. The cane workers are likely to choose the practice of burning cane as the burnt cane can be more easily cut and thus saves time. This leads to the problem of labor shortage as the cane growers cannot find the workforce for cutting green cane.

\section{Effect of high cost/low income (Fig. 2(a))}

In connection with the effect of labor shortage, the small and medium cane growers who cannot find the local workers for green cane cutting need to find the workforce from the sugar factory or a cutting machine from a large cane grower. These can contribute to a high production cost due to the high labor cost for manual cutting during the peak harvesting season or the cost of renting a cutting machine. Moreover, the lack of providing knowledge of GAPs and resource management from the private and government sector can make the cane growers have a low production yield which further contributes to the issue of low income from selling sugarcane. There are two dimensions of access to natural resources causing social issues including 1) the reduction of amount of natural resources due to which the cane growers cannot get water enough to irrigate the sugarcane; and 2) the degradation of the quality of soil fertility leading to the growers not getting adequate soil quality; both may lead to a lower yield of sugarcane production (and thus lower income - which is a social issue). This is because the growers still use the conventional practice of burnt cane cutting which can degrade the quality of topsoil. Another issue related to conventional cane cutting is the smoke and dust from burning cane during the harvesting process. So, the knowledge of GAP and resource management is crucial to mitigate the issue of access to natural resources.

Effect of labor rights and quality of life (Fig. 2(b)) 
The main causes related to labor rights and quality of life include freedom of association, wage level, equal opportunity, and skills and knowledge. As these causes affect the cane, sugar factory and ethanol factory workers, the interpretation of the cause-effect relationship should consider the nature of working conditions. The cane workers who have a legally binding work contract can leave or rest from their work based on a verbal agreement. However, the workers cannot avail paid personal/sick leave or time off from work. This is totally different from the sugar factory workers or ethanol factory workers who have written agreements with their employers to receive compensation when taking leave at least as per national and international labor treaties. In case of the freedom of association, there is legislation in Thailand covering the right of freedom of association which allows the workers to form a union or to negotiate the working conditions with the employer. However, there are also findings of limitation for worker association in some cases because the workers may not know their basic labor rights. The workers are not getting enough power to negotiate their benefits that they should obtain. Moreover, the wages for sugar and ethanol factory workers is normally the same following company regulation. However, the workers in sugarcane cultivation can get higher wages if the workers become more skilled and can harvest more.

Effect of health and safety (Fig. 2(b))

There are a few chances that accidents can occur during work on sugarcane production. However, the cane workers have a risk in the long term associated with the use of chemicals for weed and pest/disease control. The farm owner, sugar and ethanol factory should have a provision on health and safety procedures which allow their workers to easily access the equipment, knowledge or training necessary to make a health and safety feasible.

3.3.2 Social impact using a case study of biofuel systems comprising sugarcane, sugar and ethanol production

The inventory data for social indicators were collected from Sawaengsak and Gheewala (2017). The expert judgment and stakeholder satisfaction were obtained from primary sources through face-to-face interviews via questionnaires.

The results of the inventory/characterization results (CR) at the sub-category level are illustrated in Tables 4 and 5. The issue of paid wage/income being lower than the minimum wage required by law was found in all stakeholder groups. The issues of health and safety include an access to knowledge/training and to medical care, found in cane growers and cane workers. This reflects that the issue of health and safety may occur during the operating for sugarcane production. Moreover, the cane workers may be affected by the issues of the right to quality of life. The 
percentage of characterized/inventory results related to the employment relations and freedom of association and right to bargaining is relatively low. The main issue related to sugar factory workers and ethanol workers is gender equality reflected by the unbalance in the number of jobs between male and female in the factory. Moreover, fair wages is also an issue.

The adjusted performance results $\left(P R_{a d j}\right)$ derived from multiplying the actual performance results $\left(P R_{a c t}\right)$ and the adjustment factor of I and $\mathrm{S}\left(A F_{i . s}\right)$ at sub-categories level are illustrated in Tables 6 and 7 . The results show that $P R_{a c t}$ of the safety of workplace related to cane growers (S3.3, Table 6) is high (0.80), but $A F_{i . s}$ is low (0.44). This results in a low value (0.36) at the sub-category level. This means that, for example, although the farm owners provide clean drinking water to the workers during the operating time, but this seems not to be enough for the workers to obtain a proper benefit on safety of workplace. The low level of $A F_{i . s}$ is as a result from a medium level based on expert judgment on importance and worker satisfaction. This reflects the needs for addressing additional benefits on safety of workplace. Moreover, the safety of workplace (S3.3) links to S5.1 Workplace Safety and Health Provisions which is also a medium level based on expert judgment on importance and worker satisfaction. According to the interviewing with the cane growers, they did not properly provide the first aid kits, medicines or medical equipment to the workers. The transportation facility should be provided by the cane growers when the injured worker needs to attend treatment at a hospital. Therefore, providing these benefits is likely to help reduce the importance of social aspects and increase the worker satisfaction with respect to both the safety of workplace and the workplace safety and health provisions.

In case of cane workers, $P R_{a c t}$ of the freedom of association and right to bargaining (S2.4, Table 7) is very low (0.2), but $A F_{i . s}$ is high (0.67). This contributes to getting a very small value of $P R_{a d j}(0.13)$ at the sub-category level. This seems to be a critical issue if we look at the result of an actual performance indicator only as $P R_{a c t}$ is very low. The result may reflect that the cane workers do not have freedom to negotiate as groups or through a union or representatives of their choosing to set the terms of their employment. But if we consider the adjustment factor, this is somewhat a conflict resulting from a high level of worker satisfaction. This interprets that in the absence of freedom of association, this seems not to be a major problem in sugarcane production stage based on the experts' and cane workers' perspective. However, there is a possibility that the workers were not concerned because they may not know their basic labor rights to freedom of association. This can lead to a further problem if the workers did not receive fair benefits including wage/salary and welfares. The relevant authorities like the sugarcane farmer federation should give 
474 the information for the practice of fundamental freedom of association to the workers. This gives the advantage to the workers for negotiating their benefits that they should obtain from the employer.

In case of the sugar factory workers, $P R_{a c t}$ of the quality of life (S1.1, Table 7) is high (0.9), but $A F_{i . s}$ is low (0.44) giving a low value (0.4) at the sub-category level. This shows that there are no issues on the quality of life if we consider only the actual performance indicator. But looking at the adjustment factor, this seems to be a problem based on the expert and stakeholder perspective. A reason is that the worker's paid wage/salary from working at the sugar factory cannot cover the worker's living expense. Although the workers get the minimum wage/salary followed by government regulation, it cannot maintain the minimum standard of living.

The results of the rating scores of sub-categories are illustrated in Tables 8(a) and (b). The adjusted performance results $\left(P R_{a d j}\right)$ are converted to the adjusted performance score $\left(P S_{a d j}\right)$ using the rating score system. The score of the data quality of each stakeholder group is indicated in parenthesis behind the sub-categories. The moderate quality of data presented as score 2 may require improvements in the future (Table 8(b)). This can have influence on the impact results including; 1) Cane workers: employment relations; 2) Sugar factory workers: child labor, freedom of association and right to bargaining, non-discrimination, and gender equality; and 3) Ethanol factory workers: employment relations, child labor and freedom of association and right to bargaining.

The results of aggregating scores at the social category level are illustrated in Tables 9(a) and (b). The aggregation step helps to combine the relevant sub-categories into a social category. The results of the impact performance score (IPS) of different social categories can reveal the critical social issues which need to be addressed by a good agricultural practice, management or policy. However, the major issue associated with aggregating scores at the social category level is that some details of the social impacts of sub-categories may be lost. For example, a bad score in one category can be compensated by a better score in another category. 


\begin{tabular}{|c|c|c|c|c|c|}
\hline Stakeholders & Social categories & Sub-categories & Indicators & Measurement & $\begin{array}{l}\text { Inventory/ Characterized } \\
\text { results of cane growers }\end{array}$ \\
\hline \multirow{11}{*}{$\begin{array}{l}\text { Cane } \\
\text { growers/self- } \\
\text { employed } \\
\text { workers }\end{array}$} & $\begin{array}{l}\text { S1 Land } \\
\text { tenure/access and } \\
\text { displacement }\end{array}$ & S1.1 Land rights & S1.1.1 Land rights & $\begin{array}{l}\text { The percentage of growers who have the rights to use the land and } \\
\text { are not legitimately contested by local communities or other farm } \\
\text { owners with demonstrable rights }\end{array}$ & 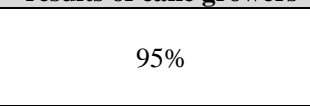 \\
\hline & $\begin{array}{l}\text { S2 Access to } \\
\text { knowledge, facility } \\
\text { and natural } \\
\text { resources }\end{array}$ & $\begin{array}{l}\text { S2.1 Access to } \\
\text { knowledge, facility } \\
\text { and natural } \\
\text { resources }\end{array}$ & $\begin{array}{l}\text { S2.1.1 Access to knowledge, } \\
\text { facility and natural } \\
\text { resources }\end{array}$ & $\begin{array}{l}\text { The percentage of growers who have access to knowledge of GAP } \\
\text { and } \mathrm{IPM}^{2} \text { from private/ government sectors. }\end{array}$ & $95 \%$ \\
\hline & \multirow[t]{4}{*}{$\begin{array}{l}\text { S3 Employment, } \\
\text { wages and labor } \\
\text { conditions }\end{array}$} & S3.1 Child labor & S3.1.1 Child labor & $\begin{array}{l}\text { Percentage of growers who do not employ below } 13 \text {-year-olds on } \\
\text { hard work which is likely to be harmful to their health or } \\
\text { development and to prejudice their attendance at school or other } \\
\text { appropriate training programs. }\end{array}$ & $90 \%$ \\
\hline & & S3.2 Forced labor & $\begin{array}{l}\text { S3.2.1 Absence of forced/ } \\
\text { compulsory labor }\end{array}$ & $\begin{array}{l}\text { Percentage of growers who do not restrict the workers in the } \\
\text { workplace area for working or force them for overtime working. }\end{array}$ & $95 \%$ \\
\hline & & $\begin{array}{l}\text { S3.3 Safety of } \\
\text { workplace }\end{array}$ & $\begin{array}{l}\text { S3.3.1 Availability of } \\
\text { sufficient safe drinking water } \\
\text { to each worker present on the } \\
\text { field and/or mill }\end{array}$ & $\begin{array}{l}\text { Percentage of growers who provide clean drinking water to the } \\
\text { workers }\end{array}$ & $73 \%$ \\
\hline & & S3.4 Fair wage & S3.4.1 Fair wage & $\begin{array}{l}\text { Percentage of growers who get paid a wage from other growers } \\
\text { for working on land preparation, cultivation and maintenance stage } \\
\text { equal to or more than the initial wage rate (minimum wage and } \\
\text { benefits required by law) }\end{array}$ & $20 \%$ \\
\hline & \multirow[t]{2}{*}{ S4 Equity } & $\begin{array}{l}\text { S4.1 Non- } \\
\text { discrimination }\end{array}$ & S4.1.1 Non-discrimination & $\begin{array}{l}\text { Percentage of growers who pay equal wage/salary to their workers } \\
\text { regardless of gender and at least the initial wage rate (minimum } \\
\text { wage required by law) regardless of work }\end{array}$ & $82 \%$ \\
\hline & & $\begin{array}{l}\text { S4.2 Gender } \\
\text { equality }\end{array}$ & S4.2.1 Gender equality & Percentage of growers who hire the workers regardless of gender & $64 \%$ \\
\hline & \multirow[t]{3}{*}{$\begin{array}{l}\text { S5 Human health } \\
\text { and safety }\end{array}$} & \multirow[t]{3}{*}{$\begin{array}{l}\text { S5.1 Safety of } \\
\text { workplace and } \\
\text { health provisions }\end{array}$} & $\begin{array}{l}\text { S5.1.1 Provide training for } \\
\text { health and safety on } \\
\text { pesticide application (if any) } \\
\text { to workers }\end{array}$ & $\begin{array}{l}\text { Percentage of growers who provide the training program to } \\
\text { workers in health and safety }\end{array}$ & $38 \%$ \\
\hline & & & $\begin{array}{l}\text { S5.1.2 Appropriate PPE } \\
\text { supplied to and used by all } \\
\text { workers }\end{array}$ & $\begin{array}{l}\text { Percentage of growers who provide an appropriate } \mathrm{PPE}^{3} \text { to and } \\
\text { used by all workers }\end{array}$ & $100 \%$ \\
\hline & & & $\begin{array}{l}\text { S5.1.3 Provide sufficient } \\
\text { health care i.e. first aid and } \\
\text { provision for emergency } \\
\text { response to workers. }\end{array}$ & $\begin{array}{l}\text { Percentage of growers who provide first aid facility and provision } \\
\text { for emergency response to workers }\end{array}$ & $53 \%$ \\
\hline
\end{tabular}

501 Table 4 The inventory/characterization results (CR) of social categories, sub-categories and indicators associated with cane growers

$502{ }^{1} \mathrm{GAP}=$ Good Agricultural Practice, ${ }^{2} \mathrm{IPM}=$ Integrated Pest Management, ${ }^{3} \mathrm{PPE}=$ Personal Protective Equipment 


\begin{tabular}{|c|c|c|c|c|c|c|c|}
\hline \multirow[b]{2}{*}{ Stakeholders } & \multirow{2}{*}{$\begin{array}{c}\text { Social } \\
\text { categories }\end{array}$} & \multirow[b]{2}{*}{ Sub-categories } & \multirow[b]{2}{*}{ Indicators } & \multirow[b]{2}{*}{ Measurement } & \multicolumn{3}{|c|}{ Inventory/Characterized results } \\
\hline & & & & & $\begin{array}{c}\text { Cane } \\
\text { plantation }\end{array}$ & $\begin{array}{c}\text { Sugar } \\
\text { factory }\end{array}$ & $\begin{array}{l}\text { Ethanol } \\
\text { factory }\end{array}$ \\
\hline Cane workers, & $\begin{array}{l}\text { S1 Decent } \\
\text { livelihood }\end{array}$ & $\begin{array}{l}\text { S1.1 Quality of } \\
\text { life }\end{array}$ & $\begin{array}{l}\text { S1.1.1 Right to } \\
\text { quality of life }\end{array}$ & Percentage of workers with time for rest at least one hour a day & $24 \%$ & $100 \%$ & $100 \%$ \\
\hline $\begin{array}{l}\text { Sugar factory } \\
\text { workers and } \\
\text { Ethanol factory }\end{array}$ & & & S1.1.2 Fair wage & $\begin{array}{l}\text { Percentage of workers who get a paid wage from the growers for } \\
\text { working on land preparation, cultivation and maintenance stage equal } \\
\text { to or more than the initial wage rate (minimum wage and benefits } \\
\text { required by law) }\end{array}$ & $67 \%$ & $63 \%$ & $48 \%$ \\
\hline \multirow{10}{*}{$\begin{array}{l}\text { Ethanol factory } \\
\text { workers }\end{array}$} & & $\begin{array}{l}\text { S1.2 Capacity } \\
\text { development }\end{array}$ & $\begin{array}{l}\text { S1.2.1 Capacity } \\
\text { development }\end{array}$ & $\begin{array}{l}\text { Percentage of workers who have the opportunities for capacity } \\
\text { development to increase their skill and knowledge via work training } \\
\text { programs }\end{array}$ & $85 \%$ & $96 \%$ & $93 \%$ \\
\hline & & $\begin{array}{l}\text { S1.3 Fair access } \\
\text { to safety } \\
\text { equipment }\end{array}$ & $\begin{array}{l}\text { S1.3.1 Fair access } \\
\text { to safety equipment }\end{array}$ & Percent of workers who can access to the equipment or protective gear & $100 \%$ & $96 \%$ & $100 \%$ \\
\hline & $\begin{array}{l}\text { S2 Labor } \\
\text { rights }\end{array}$ & $\begin{array}{l}\text { S2.1 Employment } \\
\text { relations }\end{array}$ & $\begin{array}{l}\text { S2.1.1 Employment } \\
\text { relations }\end{array}$ & $\begin{array}{l}\text { Percentage of workers who have written agreements with their } \\
\text { employers that meet at least national and international labor treaties } \\
\text { including social security }\end{array}$ & $60 \%$ & $100 \%$ & $100 \%$ \\
\hline & & S2.2 Child labor & S2.2.1 Child labor & $\begin{array}{l}\text { Percentage of workers employed who are not below } 13 \text { years of age, } \\
\text { on hard work which is likely to be harmful to their health or } \\
\text { development and to prejudice their attendance at school or other } \\
\text { appropriate training programs }\end{array}$ & $90 \%$ & $100 \%$ & $100 \%$ \\
\hline & & S2.3 Forced labor & $\begin{array}{l}\text { S2.3.1 Forced labor } \\
\text { on living place } \\
\text { limitation }\end{array}$ & $\begin{array}{l}\text { Percentage of workers who have the freedom of movement, such as } \\
\text { free from curfews or lock-ins }\end{array}$ & $95 \%$ & $90 \%$ & $100 \%$ \\
\hline & & & $\begin{array}{l}\text { S2.3.2 Forced labor } \\
\text { on overtime } \\
\text { voluntary }\end{array}$ & Percentage of workers who are not forced to work overtime & $83 \%$ & $96 \%$ & $93 \%$ \\
\hline & & $\begin{array}{l}\text { S2.4 Freedom of } \\
\text { association and } \\
\text { Right to } \\
\text { bargaining }\end{array}$ & $\begin{array}{l}\text { S2.4.1 Freedom of } \\
\text { association and } \\
\text { Right to bargaining }\end{array}$ & $\begin{array}{l}\text { Percentage of workers who have a freedom to negotiate as individuals } \\
\text { or as groups or through a union or representatives of their choosing to } \\
\text { negotiate the terms of their employment }\end{array}$ & $6 \%$ & $80 \%$ & $80 \%$ \\
\hline & S3 Equity & $\begin{array}{l}\text { S3.1 Non- } \\
\text { discrimination }\end{array}$ & $\begin{array}{l}\text { S3.1.1 Non- } \\
\text { discrimination }\end{array}$ & $\begin{array}{l}\text { Percentage of workers who have been paid equal wage/salary which } \\
\text { is at least the initial wage rate (minimum wage required by law), } \\
\text { regardless of gender or work. }\end{array}$ & $82 \%$ & $100 \%$ & $100 \%$ \\
\hline & & $\begin{array}{l}\text { S3.2 Gender } \\
\text { equality }\end{array}$ & $\begin{array}{l}\text { S3.2.1 Gender } \\
\text { equality }\end{array}$ & $\begin{array}{l}\text { Percentage of workers who are not discriminated against as women in } \\
\text { hiring, remuneration, training, and advancement, access to resources } \\
\text { or firing }\end{array}$ & $73 \%$ & $50 \%$ & $50 \%$ \\
\hline & & & $\begin{array}{l}\text { S4.1.1 Safety and } \\
\text { health training }\end{array}$ & $\begin{array}{l}\text { Percentage of workers who have been provided training in health and } \\
\text { safety by the employers }\end{array}$ & $38 \%$ & $96 \%$ & $98 \%$ \\
\hline
\end{tabular}




\begin{tabular}{lllll}
$\begin{array}{l}\text { S4 Human } \\
\text { health and } \\
\text { Safety }\end{array}$ & $\begin{array}{l}\text { S4.1 Workplace } \\
\text { Safety and Health } \\
\text { Provisions }\end{array}$ & $\begin{array}{l}\text { S4.1.2 Safety of } \\
\text { workplace and } \\
\text { facilities }\end{array}$ & Percentage of workers who have been provided clean water & $95 \%$ \\
\cline { 2 - 5 } & & $\begin{array}{l}\text { S4.1.3 Health } \\
\text { coverage and access } \\
\text { to medical care }\end{array}$ & $\begin{array}{l}\text { Percentage of workers who have been provided a first aid kit when the } \\
\text { emergency event occurs }\end{array}$ & $95 \%$ \\
\hline
\end{tabular}


507 Table 6 Adjusted performance results $\left(\mathrm{PR}_{\text {adj }}\right)$ of different sub-categories related to cane growers

\begin{tabular}{|c|c|c|c|}
\hline & \multicolumn{3}{|c|}{ Cane growers } \\
\hline & $\mathbf{P R}_{\text {act }}$ & $\mathbf{A F}_{\mathrm{i} . \mathrm{s}}$ & $\mathbf{P R}_{\text {adj }}$ \\
\hline \multicolumn{4}{|l|}{ S1 Land tenure/access and displacement } \\
\hline S1.1 Land rights & 1.0 & 0.67 & 0.67 \\
\hline \multicolumn{4}{|l|}{ S2 Access to knowledge, facility and natural resources } \\
\hline $\begin{array}{l}\text { S2.1 Access to knowledge, facility and natural } \\
\text { resources }\end{array}$ & 1.0 & 0.67 & 0.67 \\
\hline \multicolumn{4}{|l|}{ S3 Employment, wages and labor conditions } \\
\hline S3.1 Child labor & 1.0 & 0.67 & 0.67 \\
\hline S3.2 Forced labor & 1.0 & 0.67 & 0.67 \\
\hline S3.3 Safety of workplace & 0.80 & 0.44 & 0.36 \\
\hline S3.4 Fair wage & 0.20 & 0.22 & 0.04 \\
\hline \multicolumn{4}{|l|}{ S4 Equity } \\
\hline S4.1 Non-discrimination & 1 & 0.67 & 0.67 \\
\hline S4.2 Gender equality & 0.8 & 0.67 & 0.53 \\
\hline \multicolumn{4}{|l|}{ S5 Human health and safety } \\
\hline S5.1 Workplace safety and health provisions & 0.67 & 0.44 & 0.3 \\
\hline
\end{tabular}

509 Table 7 Adjusted performance results $\left(\mathrm{PR}_{\mathrm{adj}}\right)$ of different sub-categories related to cane workers, sugar factory 510 workers, and ethanol factory workers

\begin{tabular}{|c|c|c|c|c|c|c|c|c|c|}
\hline & \multicolumn{3}{|c|}{ Cane workers } & \multicolumn{3}{|c|}{$\begin{array}{c}\text { Sugar factory } \\
\text { workers }\end{array}$} & \multicolumn{3}{|c|}{$\begin{array}{c}\text { Ethanol factory } \\
\text { workers }\end{array}$} \\
\hline & $\mathbf{P R}_{\text {act }}$ & $\mathbf{A F}_{\mathrm{i} . \mathrm{s}}$ & $\mathbf{P R}_{\text {adj }}$ & $\mathbf{P R}_{\text {act }}$ & $\mathbf{A F _ { \text { i.s } }}$ & $\mathbf{P R}_{\text {adj }}$ & $\mathbf{P R}_{\text {act }}$ & $\mathbf{A F}_{\mathrm{i}}$ & $\mathbf{P R}_{\text {adj }}$ \\
\hline \multicolumn{10}{|l|}{ S1 Decent livelihood } \\
\hline S1.1 Quality of life & 0.60 & 0.44 & 0.27 & 0.90 & 0.44 & 0.40 & 0.80 & 1.00 & 0.80 \\
\hline $\begin{array}{l}\text { S1.2 Capacity } \\
\text { development }\end{array}$ & 1.00 & 0.44 & 0.44 & 1.00 & 0.67 & 0.67 & 1.00 & 1.00 & 1.00 \\
\hline $\begin{array}{l}\text { S1.3 Fair access to } \\
\text { safety equipment }\end{array}$ & 1.00 & 0.67 & 0.67 & 1.00 & 1.00 & 1.00 & 1.00 & 1.00 & 1.00 \\
\hline \multicolumn{10}{|l|}{ S2 Labor rights } \\
\hline $\begin{array}{l}\text { S2.1 Employment } \\
\text { relations }\end{array}$ & 0.60 & 0.67 & 0.40 & 1.00 & 1.00 & 1.00 & 1.00 & 1.00 & 1.00 \\
\hline S2.2 Child labor & 1.00 & 0.44 & 0.44 & 1.00 & 1.00 & 1.00 & 1.00 & 1.00 & 1.00 \\
\hline S2.3 Forced labor & 1.00 & 1.00 & 1.00 & 1.00 & 1.00 & 1.00 & 1.00 & 1.00 & 1.00 \\
\hline $\begin{array}{l}\text { S2.4 Freedom of } \\
\text { association and right to } \\
\text { bargaining }\end{array}$ & 0.2 & 0.67 & 0.13 & 0.80 & 1.00 & 0.80 & 0.80 & 1.00 & 0.80 \\
\hline \multicolumn{10}{|l|}{ S3 Equity } \\
\hline $\begin{array}{l}\text { S3.1 Non- } \\
\text { discrimination }\end{array}$ & 1.0 & 0.67 & 0.67 & 1.00 & 0.67 & 0.67 & 1.00 & 1.00 & 1.00 \\
\hline S3.2 Gender equality & 0.80 & 0.67 & 0.53 & 0.60 & 1.00 & 0.60 & 0.60 & 1.00 & 0.60 \\
\hline \multicolumn{10}{|l|}{ S4 Human health and Safety } \\
\hline $\begin{array}{l}\text { S4.1 Workplace safety } \\
\text { and health provisions }\end{array}$ & 0.67 & 0.67 & 0.44 & 1.00 & 1.00 & 1.00 & 1.00 & 1.00 & 1.00 \\
\hline
\end{tabular}

512 Table 8 The adjusted performance score and data quality score (indicated in parenthesis) related to stakeholders at 513 sub-category level; (a) cane growers, (b) cane workers, sugar factory workers and ethanol workers

(a) Cane growers

\begin{tabular}{lc}
\hline \multicolumn{1}{c}{ Sub-categories } & Cane growers \\
\hline S1.1 Land rights (3) & $\mathbf{4}$ \\
\hline S2.1 Access to knowledge, facility and natural resources (3) & $\mathbf{4}$ \\
\hline S3.1 Child labor (3) & 4 \\
\hline S3.2 Forced labor (3) & 4 \\
\hline S3.3 Safety of workplace (3) & $\mathbf{2}$ \\
\hline
\end{tabular}




\begin{tabular}{l|l}
\hline S3.4 Fair wage (3) & 1 \\
\hline S4.1 Non-discrimination (3) & $\mathbf{4}$ \\
\hline S4.2 Gender equality (3) & $\mathbf{3}$ \\
\hline S5.1 Workplace safety and health provisions (3) & $\mathbf{2}$ \\
\hline
\end{tabular}

515 (b) Cane workers, Sugar factory workers and ethanol factory workers

\begin{tabular}{lccc}
\hline \multicolumn{1}{c}{ Sub-categories } & $\begin{array}{c}\text { Cane } \\
\text { workers }\end{array}$ & $\begin{array}{c}\text { Sugar } \\
\text { factory } \\
\text { workers }\end{array}$ & $\begin{array}{c}\text { Ethanol } \\
\text { factory } \\
\text { workers }\end{array}$ \\
\hline S1.1 Quality of life $(3,3,3)$ & $\mathbf{2}$ & $\mathbf{2}$ & $\mathbf{4}$ \\
\hline S1.2 Capacity development $(3,3,3)$ & $\mathbf{3}$ & $\mathbf{4}$ & $\mathbf{5}$ \\
\hline S1.3 Fair access to means of production $(3,3,3)$ & $\mathbf{4}$ & $\mathbf{5}$ & $\mathbf{5}$ \\
\hline S2.1 Employment relations $(2,3,2)$ & $\mathbf{2}$ & $\mathbf{5}$ & $\mathbf{5}$ \\
\hline S2.2 Child labor $(3,2,2)$ & $\mathbf{3}$ & $\mathbf{5}$ & $\mathbf{5}$ \\
\hline S2.3 Forced labor $(3,3,3)$ & $\mathbf{5}$ & $\mathbf{5}$ & $\mathbf{5}$ \\
\hline S2.4 Freedom of association and Right to bargaining & $\mathbf{1}$ & $\mathbf{4}$ & $\mathbf{4}$ \\
\hline 3, 2, 2) & $\mathbf{4}$ & $\mathbf{4}$ & $\mathbf{5}$ \\
\hline S3.1 Non-discrimination $(3,2,3)$ & $\mathbf{3}$ & $\mathbf{3}$ & $\mathbf{3}$ \\
\hline S4.1 Wonder equality (3, 2, 3) & $\mathbf{3}$ & $\mathbf{5}$ & $\mathbf{5}$ \\
\hline
\end{tabular}

516

517

518

519

Table 9 Aggregated score of stakeholders at social category level; (a) cane growers, (b) cane workers, sugar factory workers and ethanol workers at social category level

(a) Cane growers

\begin{tabular}{lc}
\hline \multicolumn{1}{c}{ Social categories } & Cane growers \\
\hline S1 Land tenure/access and displacement & $\mathbf{4}$ \\
\hline S2 Access to knowledge, facility and natural resources & $\mathbf{4}$ \\
\hline S3 Employment, wages and labor conditions & $\mathbf{3}$ \\
\hline S4 Equity & $\mathbf{4}$ \\
\hline S5 Human health and safety & $\mathbf{2}$ \\
\hline
\end{tabular}

(b) Cane workers, Sugar factory workers and Ethanol factory workers

\begin{tabular}{lccc}
\hline \multicolumn{1}{c}{ Social categories } & $\begin{array}{c}\text { Cane } \\
\text { workers }\end{array}$ & $\begin{array}{c}\text { Sugar } \\
\text { factory } \\
\text { workers }\end{array}$ & $\begin{array}{c}\text { Ethanol factory } \\
\text { workers }\end{array}$ \\
\hline S1 Decent livelihood & 3 & 4 & 5 \\
\hline S2 Labor rights & 3 & 5 & 5 \\
\hline S3 Equity & 4 & 4 & 4 \\
\hline S4 Human health and safety & 3 & 5 & 5 \\
\hline
\end{tabular}

This study is very different from other studies which used the impact pathway (Parent et al. 2010; Feschet et al. 
the impact pathway. This study on the other hand illustrates the cause-effect relationship towards the social issues associated with stakeholders as described in Section 3.3.1. The advantage of using the cause and effect chain is that the specific indicators can be identified based on the social issues at the site. However, using a scale-based assessment may lead to subjectivity in the results and can cause a higher uncertainty (Carmo et al. 2017a). Some social impacts including human health and safety, employment and salary can be assessed through the impact pathways-based impact assessment method to receive more reliable social impact (Fontes 2014; Weldegiogis and Franks 2014; Kruse et al. 2008). Therefore, the scale-based method can be improved by combining with impact pathways-based method; this is one of the limitations of this study that needs further development.

The characterized results of this study are obtained based on measurements of social performance and expert judgment compared against compliance with norms. There is a similar approach studied by Manik et al. (2013) where characterization was performed by combining the result of weighting the expert judgment and gauging stakeholder perspective. One pivotal difference between this study and Manik et al. (2013) is that this study rates the stakeholder perspective according to the level of satisfaction of social issues instead of measuring the gaps between expected and perceived value of each social indicator.

In summary, this developed framework and method are likely to be systematically comprehensive with respect to the social impact of a production system. Table 10 presents how the proposed framework and methodology can address the weaknesses in the methodology used by the previous studies. The cause-effect analysis can be applied for distinguishing the specific social issues in this study. The appropriate indicators, sub-categories and social categories can be used as the information for communicating with the stakeholders. This study selected experts from two sectors including the government sector and the private sector. Moreover, the stakeholder satisfaction on social issues has also been accounted in order to minimize the biased judgment given by the experts. The results of the social performance level of different sub-categories and social categories can facilitate the decision-making on social development policy. However, this needs to be improved for some indicators by combining scale-based and impact pathways-based method. Moreover, the approaches to weighing the importance of social aspects and satisfaction according to stakeholders or experts need to be improved to make this more objective. In addition, the uncertainty of the subcategory indicators aggregated into stakeholder groups needs to be accounted. This is because the aggregation implies a loss of detailed information making it difficult to see the impacts on the each of the social categories. Thus, the uncertainty related to the scoring choice and the weighting factors are likely to be identified by using uncertainty 
model choice and Monte Carlo simulation (Carmo et al. 2017a). Moreover, the improved characterization model should be adopted in order to obtain the result validation. As this study focused on the social issues related to the production of sugarcane, sugar, and ethanol, therefore the perception of the customers and consumers regarding consumption aspects is not used to make the assessment. However, the use stage of a product is essential to be assessed.

Table 10 Comparison of the characteristics of the methodology from previous studies with the proposed framework and method

\begin{tabular}{|c|c|c|c|c|}
\hline $\begin{array}{c}\text { Focus on } \\
\text { developing } \\
\text { framework }\end{array}$ & $\begin{array}{c}\text { Characteristics of } \\
\text { existing S-LCA } \\
\text { methodology }\end{array}$ & $\begin{array}{l}\text { Methodological } \\
\text { Weaknesses }\end{array}$ & $\begin{array}{c}\text { Needs for } \\
\text { Improvement }\end{array}$ & $\begin{array}{c}\text { Outcomes from } \\
\text { proposed } \\
\text { framework/method }\end{array}$ \\
\hline $\begin{array}{l}\text { Selecting of } \\
\text { indicators }\end{array}$ & $\begin{array}{l}\text { - Apply risk } \\
\text { management } \\
\text { techniques in multi- } \\
\text { criteria indicator } \\
\text { model (Dreyer et al. } \\
\text { 2010) } \\
\text { - Semi-quantitative } \\
\text { indicators used for } \\
\text { the assessment } \\
\text { (Aparcana and } \\
\text { Salhofer 2013a; } \\
\text { Foolmaun and } \\
\text { Ramjeeawon 2013) }\end{array}$ & $\begin{array}{l}\text { - Direct indicators } \\
\text { cannot explain the } \\
\text { complexities } \\
\text { associated with social } \\
\text { issues } \\
\text { - The social impacts are } \\
\text { assumed to be only } \\
\text { qualitative. This needs } \\
\text { further research }\end{array}$ & $\begin{array}{l}\text { - Incorporating the } \\
\text { causal } \\
\text { relationships and } \\
\text { aggregating the } \\
\text { indicators with a } \\
\text { scoring system }\end{array}$ & $\begin{array}{l}\text { The cause and effect } \\
\text { chain can be used to } \\
\text { identify the specific } \\
\text { social issues at the site } \\
\text { - Appropriate indicators, } \\
\text { sub-categories and } \\
\text { social categories will } \\
\text { be used as the } \\
\text { information for } \\
\text { communicating with } \\
\text { the stakeholders }\end{array}$ \\
\hline $\begin{array}{l}\text { Scaling of } \\
\text { inventory data }\end{array}$ & $\begin{array}{l}\text { Using the multi-level } \\
\text { scales (Ciroth and } \\
\text { Franze 2011; } \\
\text { Foolmaun and } \\
\text { Ramjeeawon 2013; } \\
\text { Sanchez Ramirez et } \\
\text { al. 2014) } \\
\text { Weighting the social } \\
\text { expectations and } \\
\text { perceptions of social } \\
\text { issues by using a } \\
\text { seven-point Likert } \\
\text { scale (Manik et al. } \\
\text { 2013; Aparcana and } \\
\text { Salhofer 2013a) }\end{array}$ & $\begin{array}{l}\text { Some subjective } \\
\text { experiences occur } \\
\text { from the scoring } \\
\text { process based on the } \\
\text { investigator's } \\
\text { personal judgment } \\
\text { and a manager's } \\
\text { personal responses to } \\
\text { the questions } \\
\text { The experts would } \\
\text { introduce biased } \\
\text { judgment of the } \\
\text { importance for every } \\
\text { impact category }\end{array}$ & $\begin{array}{l}\text { - Developing an } \\
\text { appropriate } \\
\text { weighting scheme } \\
\text { considering the } \\
\text { relative } \\
\text { importance of } \\
\text { social aspects, and } \\
\text { aggregating the } \\
\text { characterization } \\
\text { result into impact } \\
\text { categories, } \\
\text { stakeholder } \\
\text { categories, or even } \\
\text { in a single score }\end{array}$ & $\begin{array}{l}\text { - Important of social } \\
\text { aspects is well } \\
\text { established in the } \\
\text { framework to number } \\
\text { the important levels of } \\
\text { relevant social issues } \\
\text { - Stakeholder } \\
\text { satisfaction on social } \\
\text { issues included in the } \\
\text { framework to } \\
\text { minimize the biased } \\
\text { judgment given by the } \\
\text { experts. }\end{array}$ \\
\hline
\end{tabular}




\begin{tabular}{|c|c|c|c|c|}
\hline $\begin{array}{c}\text { Focus on } \\
\text { developing } \\
\text { framework }\end{array}$ & $\begin{array}{l}\text { Characteristics of } \\
\text { existing S-LCA } \\
\text { methodology }\end{array}$ & $\begin{array}{c}\text { Methodological } \\
\text { Weaknesses }\end{array}$ & $\begin{array}{c}\text { Needs for } \\
\text { Improvement }\end{array}$ & $\begin{array}{c}\text { Outcomes from } \\
\text { proposed } \\
\text { framework/method }\end{array}$ \\
\hline Characterization & $\begin{array}{l}\text { Using a norm-based } \\
\text { PRPs assessment } \\
\text { determined through } \\
\text { expert judgment } \\
\text { (Ciroth and Franze } \\
\text { 2011; Quantis et al. } \\
\text { 2012; Fontes 2014) }\end{array}$ & $\begin{array}{l}\text { - Some impact categories } \\
\text { cannot be determined } \\
\text { through expert } \\
\text { judgment }\end{array}$ & $\begin{array}{l}\text { - Providing the basis } \\
\text { for the use of PRPs } \\
\text { in Type I } \\
\text { assessment } \\
\text { methods and a } \\
\text { consistent } \\
\text { characterization for } \\
\text { impact categories } \\
\text { and subcategories }\end{array}$ & $\begin{array}{l}\text { The social } \\
\text { performance level of } \\
\text { different sub- } \\
\text { categories and social } \\
\text { categories can } \\
\text { facilitate the decision- } \\
\text { making on social } \\
\text { development policy }\end{array}$ \\
\hline $\begin{array}{l}\text { Weighting } \\
\text { methods }\end{array}$ & $\begin{array}{l}\text { Manik et al. (2013) } \\
\text { focus on a range of } \\
\text { third-party } \\
\text { stakeholders (from } \\
\text { academia, activist } \\
\text { organizations, NGOs, } \\
\text { and governmental } \\
\text { agencies) } \\
\text { Hosseinijou et al. } \\
\text { (2014) focus on } 20 \\
\text { experts, mostly from } \\
\text { the technical and } \\
\text { business fields }\end{array}$ & $\begin{array}{l}\text { - The results of the social } \\
\text { assessment may be } \\
\text { different depending on } \\
\text { the set of stakeholders } \\
\text { selected. }\end{array}$ & $\begin{array}{l}\text { Covering all } \\
\text { dimensions of } \\
\text { social aspects } \\
\text { collected from } \\
\text { different experts } \\
\text { and stakeholders }\end{array}$ & $\begin{array}{l}\text { Encompass } \\
\text { comprehensively the } \\
\text { issues of concern } \\
\text { related to stakeholder } \\
\text { groups by establishing } \\
\text { the weighting } \\
\text { approach for the } \\
\text { expert judgment and } \\
\text { stakeholder } \\
\text { satisfaction }\end{array}$ \\
\hline
\end{tabular}

The application to the case study is conducted to provide a basis for discussion and consider the meaningful

564 interpretation of the results for using the developed method. The results of adjusted performance score at sub-category level (Table 8a,b) are used to interpret the main social issues related to stakeholders. The low level of a score 1 or 2 reflects the strong need for improvement. Based on the results, the social issues of safety of the workplace, fair wage, and workplace safety and health provisions related to the cane growers require improvement provided by the government and private sector (sugar factory) with respect to a knowledge and skills training program. Moreover, the

569 issues of quality of life, employment relations and freedom of association and right to bargaining related to the cane 570 workers need to be urgently improved. As the quality of life consists of the right of quality of life and fair wage, the 571 farm owner should at least provide the rest time of one hour a day and give at least the legal minimum wage to cane workers in order to achieve compliance with the National law and Bonsucro Standard. Nevertheless, the social issue

573 of employment relations related to the cane workers should be a written agreement required by national and

574 international labor laws for workers. This can also raise awareness of the cane workers about their right to freedom of 
association and right to bargaining of their employment. The sugar and ethanol factory workers seem not to have many issues except the quality of life related to sugar factory workers.

The low level of a performance adjusted score is obtained from either low performance actual score or low adjustment factor. The latter seems to have hardly affected the result of the impact sub-categories and social categories. On the other hand, the sub-categories of quality of life, employment relations, child labor, and gender equality, related to cane workers are affected more substantially. The sub-category of quality of life related to sugar factory workers received a large effect from the weighting of the importance of social aspects and satisfaction. The developed social impact assessment method can give an accurate and reliable impact result since the characterized/inventory results can be improved by using the weighting factor of the importance of social aspects and satisfaction. However, the weighting score of the importance of social aspects and satisfaction are accounted as a traditional weighting score approach (linear scale score) (Carmo et al. 2017b). The process for translating the qualitative performance of indicators into a quantitative assessment may not cover the complexity of the social indicators. The customized score which develops specific value functions for each social indicator is more realistic than the linear score. Carmo and colleagues (2017b) claimed that this can better capture the complexity of the social indicators, subcategories and categories based on expert judgment.

The results of the actual and adjusted performance scores of the same sub-category or performance indicator can be compared to manifest and interpret the magnitude of difference. However, it is not important how much the scores are varied among the sub-categories or performance indicators; rather it is important to see which result is better or worse than another. For instance, the sub-category related to employment relations which is about binding work contract between employer and employee is different for the cane workers and sugar factory workers. The actual performance result related to employment relations on which the farm owners have written agreements with their cane workers at least meets the national labor standard, showing its value to be 0.6 . Although this was relevant to the actual and adjusted performance result of the sugar factory workers, the cane workers did not feel satisfied as legally binding contracts did not meet the labor laws with respect to safety, inadequate living and working conditions offered by the employers.

\section{Conclusions}

The study aims to develop social impact assessment framework and method which can apply to all the sectors. Four steps were taken to achieve the performance score of different social categories, sub-categories and indicators 
603

604

605

606

607

608

609

610

611

612

613

614

615

616

617

618

619

620

621

622

623

624

625

626

627

628

629

630

related to stakeholders group and sectors including; 1) providing the social categories, sub-categories, and indicators, 2) measuring the inventory/characterization results of indicators, 3) determining the stakeholder perspective of the importance of social aspects, quality and data and satisfaction of sub-categories, and 4) aggregation of results.

The establishment of cause-effect relationship in the very beginning step in the framework can help to define the specific social issues to address the appropriate sub-categories and performance indicators and can play an important role which can be allowed to change for other sectors. Moreover, there are some advantages of cause-effect relationship which can link to the weighting of the importance of concerns and satisfaction related to the social issues. As the cause-effect chain derives from the stakeholder and expert perspective which contributes to the performance score of sub-categories, this can reflect on the numbers behind the performance score. As an added complexity, some social causes may contribute to more than a single effect of social issues. The cause-effect relationship can help not only defining the set of specific social issues to meet the appropriate sub-categories and performance indicators but also facilitate the data collection. The specific social issues should be relevant to the social categories, sub-categories and performance indicator. Moreover, the cause-effect chain can explicitly show the relationship between social categories and sub-categories.

The establishment of the weighting score of the importance of social aspects (I) and satisfaction (S) can, therefore, assist in the trade-off of social issues to be given more accurate and reliable impact results. The perception of importance of social aspects and satisfaction can be a basis of the subjective result to a specific performance indicator. Although the score rating of importance of social aspects and satisfaction may introduce a biased judgment, the inclusion of expert opinion and stakeholder perspective can better reflect the potential impact of product system than using the international standard alone as a norm. Nevertheless, the physical/personal inspection of sugarcane farms, sugar and ethanol factories may also be useful for considering the ground reality of context and situation of some social issues. This can provide the score rating a more solid background and thus a more reliable value for the decisionmaking process. Additionally, a satisfaction survey of stakeholders should be performed as it illustrates the stakeholder perspectives at the specific timeframe and context regarding the social issues. Matching the results of the perspectivebased score rating with the results of social impact assessment will support the importance of the social aspects.

In the case study, five relevant impact categories of cane growers were identified including; 1) land tenure; 2) employment, wages, and labor conditions; 3) access to knowledge and facilities; 4) equity; and 5) health and safety. On the other hand, the four relevant impact categories of cane workers, sugar factory workers, and ethanol factory 
631

632

633

634

635

636

637

638

639

640

641

642

643

644

645

646

647

648

649 workers were; 1) decent livelihood; 2) labor rights; 3) equity; and 4) human health and safety. As a result, the social issues of safety of the workplace, fair wage, and workplace safety and health provisions related to the cane growers represent the crucial points where improvement needs to be made by the government (agricultural extension office) and private sector (sugar factory). Moreover, the issues of quality of life, employment relations and freedom of association and right to bargaining related to the cane workers require improvement urgently.

The situation is, however, contrasted with regard to the sugar and ethanol factory workers. Although the quality of life related to the sugar factory workers seems to be an issue, this is likely to be biased based on their perceived satisfaction. However, this can bring awareness of the socioeconomic risks and the improvement of the satisfaction requiring deeper analysis.

The limitation of the study is that the method for assessing social impact can only be applied for foreground data involved with stakeholders. Nonetheless, the method might not be suitable for using the background data due to changing stakeholder perceptions and expectations depending on the different timeframes and locations. As the study looked at the social issues related to the production of sugarcane, sugar and ethanol, the perception of the customers and consumers regarding consumption aspects is not used in the assessment. Moreover, the multi-question or triangulation technique to verify the collected data needs to be considered to confirm the same understanding between the interviewer and interviewee and to enable a more reliable assessment. The data quality of social issues associated with sugar factory workers and ethanol factory workers including child labor, freedom of association and right to bargaining, non-discrimination, and gender equality, should be improved to give more reliability. On the other hand, the data quality related to cane workers including employment relations and the safety of the workplace, operations, and facilities, may not reflect reality accurately; these should be also improved in the future.

\section{Acknowledgments}

The research has been carried out under the thesis "Social Assessment of Biofuel Systems in Thailand" supported by the Thailand Research Fund under the Royal Golden Jubilee Ph.D. program (Grant PHD/0124/2559) and the project "Research Network for LCA and Policy on Food, Fuel and Climate Change supported by the National Science and Technology Development Agency, Thailand as well as the Joint Graduate School of Energy and Environment, King Mongkut's University of Technology Thonburi, Thailand and Department of Management Engineering, Technical University of Denmark. 


\section{References}

Aparcana S, Salhofer S (2013a) Development of a social impact assessment methodology for recycling systems in low-income countries. Int J Life Cycle Assess 18:1106-1115. DOI: 10.1007/ s11367-013-0546-8

Blok K, Huijbregts M, Roes L, van Haaster B, Patel M, Hertwich E, Wood R, Hauschild MZ, Sellke P, Antunes P, Hellweg S, Ciroth A, Harmelink M (2013) A Novel Methodology for the Sustainability Impact Assessment of New Technologies. The EC 7th framework project, Utrecht, Netherland

Bonsucro (2014) Bonsucro Production Standard Version 4.01. Bonsucro, London, UK

Chhipi-Shrestha GK, Hewage K, Sadiq R (2015) "Socializing" Sustainability: A Critical Review on Current Development Status of Social Life Cycle Impact Assessment Method. Clean Technol Envir 17(3): 579-596. DOI: $10.1007 / \mathrm{s} 10098-014-0841-5$

Ciroth A, Franze J (2011) LCA of an ecolabeled notebook: consideration of social and environmental impacts along the entire life cycle. Federal Public Planning Service Sustainable Development, Brussels, Belgium

Dreyer LC (2006) Interpretation of the Fundamental ILO Conventions into Business Context Background for development of indicators for Social LCA. Department of Manufacturing Engineering and Management, Technical University of Denmark, Lyngby, Denmark

Dreyer LC, Hauschild MZ, Schierbeck J (2010) Characterisation of social impacts in LCA part 1: development of indicators for labor rights. Int J Life Cycle Assess 15:247-259. DOI: 10.1007/s11367-009-0148-7

Carmo BBT, Margni M, Baptiste P (2017a) Addressing uncertain scoring and weighting factors in social life cycle assessment. Int J Life Cycle Assess 22: 1609-1617. DOI: 10.1007/s11367-017-1275-1

Carmo BBT, Margni M, Baptiste P (2017b) Customized scoring and weighting approaches for quantifying and aggregating results in social life cycle impact assessment. Int J Life Cycle Assess 22: 2007-2017. DOI $10.1007 / \mathrm{s} 11367-017-1280-4$

FAO (2011) The Global Bioenergy Partnership (GBEP) sustainability indicators for bioenergy. Food and Agriculture Organization of the United Nations, Rome, Italy. http://www.globalbioenergy.org/fileadmin/user_upload/gbep/docs/Indicators/The_GBEP_Sustainability_Indic ators_for_Bioenergy_FINAL.pdf 
684 FAO (2014) Sustainability Assessment of Food and Agriculture Systems guidelines version 3.0. Natural Resources

685

686

687

688

689

690

691

692

693

694

695

696

697

698

699

700

701

702

703

704

705

706

707

708

709

Management and Environment Department, Food and Agriculture Organization of the United Nations, Rome, Italy. DOI: http://www.fao.org/3/a-i3957e.pdf

Feschet P, Macombe C, Garrabe' M, Loeillet D, Saez AR, Benhmad F (2012) Social impact assessment in LCA using the Preston pathway. Int J Life Cycle Assess 18: 490-503. DOI: 10.1007/s11367-012-0490-z

Fontes J (2014) Handbook for product social impact assessment, Roundtable for Product Social Metrics. 137p

Foolmaun R, Ramjeeawon T (2013) Comparative life cycle assessment and social life cycle assessment of used polyethylene terephthalate (PET) bottles in Mauritius. Int J Life Cycle Assess 18: 155-171. DOI: $10.1007 / \mathrm{s} 11367-012-0447-2$

Giner-Santonja G, Aragonés-Beltrán P, Niclós-Ferragut J (2012) The application of the analytic network process to the assessment of best available techniques. J Clean Prod 25: 86-95. DOI: 10.1016/j.jclepro.2011.12.012

Hosseinijou SA, Mansour S, Shirazi MA (2014) Social Life Cycle Assessment formaterial selection: a case study of buildingmaterials. Int J Life Cycle Assess 19(3):620-645. DOI: 10.1007/s11367-013-0658-1

Ibáñez-Forés V, Bovea MD, Pérez-Belis V (2014) A holistic review of applied methodologies for assessing and selecting the optimal technological alternative from a sustainability perspective. J Clean Prod 70: 259-281. DOI: http://dx.doi.org/10.1016/j.jclepro.2014.01.082

ISO 14044, 2006. Environmental management - Life cycle assessment - Requirements and guidelines

Jørgensen A, Le Bocq A, Nazarkina L, Hauschild M (2008) Methodologies for Social Life Cycle Assessment. Int J Life Cycle Assess 13 (2): 96-103. DOI: http://dx.doi.org/10.1065/lca2007.11.367

Kruse SA, Flysjö A, Kasperczyk N, Scholz AJ (2008) Socioeconomic indicators as a complement to life cycle assessment—an application to salmon production systems. Int J Life Cycle Assess 14(1):8-18. DOI: $10.1007 / \mathrm{s} 11367-008-0040-\mathrm{x}$

Kroeger A, Weber C (2014) Developing a conceptual framework for comparing social value creation. Acad Manage Rev 39 (4): 513-540. DOI: 10.5465/amr.2012.0344

Manik Y, Leahy J, Halog A (2013) Social life cycle assessment of palm oil biodiesel: a case study in Jambi province of Indonesia. Int J Life Cycle Assess 18: 1386-1392. DOI: 10.1007/s11367-013-0581-5 
Martín-Gamboa M, Iribarren D, García-Gusano D, Dufour J (2017) A review of life-cycle approaches coupled with data envelopment analysis within multi-criteria decision analysis for sustainability assessment of energy systems. J Clean Prod 150: 164-174. DOI: https://doi.org/10.1016/j.jclepro.2017.03.017

Parent J, Cucuzzella C, Revéret JP (2010) Impact assessment in SLCA: sorting the sLCIA according to their outcomes. Int J Life Cycle Assess 15: 164-171. DOI: 10.1007/s11367-009-0146-9

Quantis, Agéco, Ciraig (2012) Environmental and socioeconomic life cycle analysis of Canadian milk. Montréal. 253 p. https://www.dairyresearch.ca/pdf/LCA-DFCFinalReport_e.pdf

Russo Garrido S, Parent J, Beaulieu L, Revéret JP (2018) A literature review of type I SLCA - making the logic underlying methodological choices explicit. Int J Life Cycle Assess 23: 432-444. DOI: 10.1007/s11367-016$1067-\mathrm{z}$

Sanchez Ramirez PKS, Petti L, Haberland NT, Lie Ugaya CM (2014) Subcategory assessment method for Social Life Cycle Assessment. Part 1: methodological framework. Int J Life Cycle Assess 19(8): 1515-1523. DOI: 10.1007/s11367-014-0761-y

Sawaengsak W, Gheewala SH (2017) Analysis of social and socio-economic impacts of sugarcane production: A case study in Nakhon Ratchasima province of Thailand. J Clean Prod 142: 1169-1175. DOI: https://doi.org/10.1016/j.jclepro.2016.08.148

Spillemaeckers S, Vanhoutte G, Taverniers L, Lavrysen L, van Braeckel D, Mazijn B, Rivera JD (2004) Ecological, social and economical aspects of integrated product policy. Integrated product assessment: the development of the label 'sustainable development' for products, Belgian Science Policy, Brussels, Belgium

Traverso M, Asdrubali F, Francia A, Finkbeiner M (2012) Towards life cycle sustainability assessment: an implementation to photovoltaic modules. Int J Life Cycle Assess 17:1068-1079. DOI 10.1007/s11367-0120433-8

UNEP (2009) Guidelines for social life cycle assessment of products. United Nations Environment Program, Paris, France. http://www.unep.fr/shared/publications/pdf/dtix1164xpa-guidelines_slca.pdf

Wang JJ, Jing YY, Zhang CF, Zhao JH (2009) Review on multi-criteria decision analysis aid in sustainable energy decision-making. Renew Sust Energ Rev 13: 2263-2278. DOI: https://doi.org/10.1016/j.rser.2009.06.021

Weidema BP (2006) The integration of economic and social aspects in life cycle impact assessment. Int J Life Cycle Assess 11(1): 89-96. DOI: http://dx.doi.org/10.1065/lca2006.04.016 
738 Weldegiogis GS, Franks DM (2014) Social dimensions of energy supply alternatives in steelmaking: comparison of biomass and coal production scenarios in Australia. J Clean Prod 84:281-288. DOI: https://doi.org/10.1016/j.jclepro.2013.09.056

741 Wu SR, Yang D, Chen J (2014) Social Life Cycle Assessment revisited. Sustainability 6(7):4200-4226. DOI:10.3390/su6074200

743 Yang QZ, Chua BH, Song B (2009) A matrix evaluation model for sustainability assessment of manufacturing 744 technologies, International Journal of Industrial and Manufacturing Engineering 3(8): 953-958

745 Yu OY, Guikema SD, Briaud JL, Burnett D (2012) Sensitivity analysis for multi attribute system selection problems 746 in onshore environmentally friendly drilling (EFD). Syst Eng 15 (2): 153-171. DOI: 10.1002/sys.20200 
Click here to access/download

\section{Supplementary Material ESM.docx}

